\title{
Dispersed organic matter characteristics as an indicator of rock alteration degree of the Safyanovskoe copper-sulphide deposit (Middle Urals)
}

\author{
Elena Industrovna SOROKA ${ }^{1 *}$, \\ Akhmet Askhatovich GALEEV ${ }^{2}$, \\ Vera Igorevna PETROVA ${ }^{3}$, \\ Vladimir Pavlovich LYUTOEV ${ }^{* *}$, \\ Lubov' Vladimirovna LEONOVA ${ }^{* * *}$ \\ ${ }^{1}$ The Zavaritsky Institute of Geology and Geochemistry of the Ural Branch of RAS, Ekaterinburg, Russia \\ ${ }^{2}$ Kazan (Volga region) Federal University, Kazan, Russia \\ ${ }^{3}$ VNIIOkeangeologia, Saint Petersburg, Russia \\ ${ }^{4}$ Institute of Geology Komi Science Centre of the Ural Branch of RAS, Syktyvkar, Russia
}

\section{Annotation}

Relevance of the study is due to the importance of composition and maturity of the dispersed organic matter (DOM) as indicators of rock forming conditions, which may contribute to the paleoecological reconstruction of sedimentation conditions for rocks in the ore-bearing stratum of the Safyanovskoe deposit.

Objective: to analyze the composition and characteristics of DOM in carbon-siliceous rocks of the ore-bearing stratum of the Safyanovsky copper-pyrite deposit. The obtained characteristics of the DOM make it possible to reveal the source of original accumulation and the level of its transformation under the influence of various geological processes.

Methods. A detailed study of DOM was carried out by the EPR method (electron paramagnetic resonance) for powder preparations. EPR spectra were recorded at room temperature on X-band spectrometers DX-70, ESR 70-03 DX/2, and SE/X-2547 RadioPAN. The analytical procedure for studying organic matter (OM) included: determination of insoluble residue and $\mathrm{C}_{\text {org }}$ content in the rock, extraction of the chloroform bitumoids $(\mathrm{CB})$ and the alcohol-benzol bitumoids (ABB), humic acids (HA), determining the group composition of $\mathrm{CB}$ and hydrocarbons (HC), chromatographic fractionation with determination of the sum of methane-naphthenic and aromatic fractions of hydrocarbons, GC-MS analysis of n-alkanes, cyclic and polyaromatic hydrocarbons (PAHs). GC-MS analysis was performed on the complex Hewlett Packard 6850/5973 with a quadrupole mass detector and analytical information processing software.

Results. Analysis of the EPR spectra of carbon-siliceous rocks of the Safyanovskoe deposit showed the presence of the two types of carbon signal (C-org), characteristic of the plant and the animal residues. It was also found that the DOM has never been exposed to temperatures greater than $300^{\circ} \mathrm{C}$. Geochemical analysis of OM indicates that DOM is at a high maturation stage (residual organic matter $(\mathrm{ROM})>99 \%)$. But the type of distribution of polyaromatic hydrocarbons (PAHs) suggests that the primary OM was specifically altered at elevated temperatures.

Conclusions. DOM of carbon-siliceous rocks of the Safyanovsky deposit is genetically the same, its type is mainly sapropelic and accumulation is associated with marine conditions. A characteristic feature is, on the one hand, its high polymerization, which is typical for DOM of the stage of late mesocatagenesis, and, on the other hand, its molecular composition does not allow us to talk about the maturation of DOM in the process of natural regional metamorphism.

Keywords: Safyanovskoe copper-pyrite deposit, carbon-siliceous rocks, dispersed organic matter (DOM), hydrocarbons, electron paramagnetic resonance, paramagnetic organic radicals.

\section{Introduction}

Safyanovskoe deposit is located within the East Urals rise in the southern part of the Rezhevskaya structural-formational zone (Fig. 1). It is localized in the altered volcanic and volcano-sedimentary rocks of acid-medium composition, which opened in the career of the Main ore deposit.

Main ore body of massive pyrite ores has a length of 400 $\mathrm{m}$ and a width of up to $140 \mathrm{~m}$. The southern flank of the ore body rapidly tapers out, and the northern passes in a series of apophyses, which are represented by massive pyrite, copper-zinc and vein-disseminated sulfide ores [1]. Host rocks tectonically elaborated, brecciated and hydrothermally altered. Ore-hosting strata has a capacity of approximately $500 \mathrm{~m}$.

Carbon-bearing-siliceous rocks are part of the ore-hosting strata in the form of benches with thickness ranging from 0.1 to $1.5 \mathrm{~m}$ and contain $\mathrm{C}_{\text {org }} 4-6 \%$ [2]. They opened by quarry and at a depth of more than $200 \mathrm{~m}$ - by mine working

\footnotetext{
\soroka@igg.uran.ru

(3ttps://orcid.org/0000-0003-1360-6274

https://orcid.org/0000-0003-0231-302X

Ivleonova@yandex.ru
} 


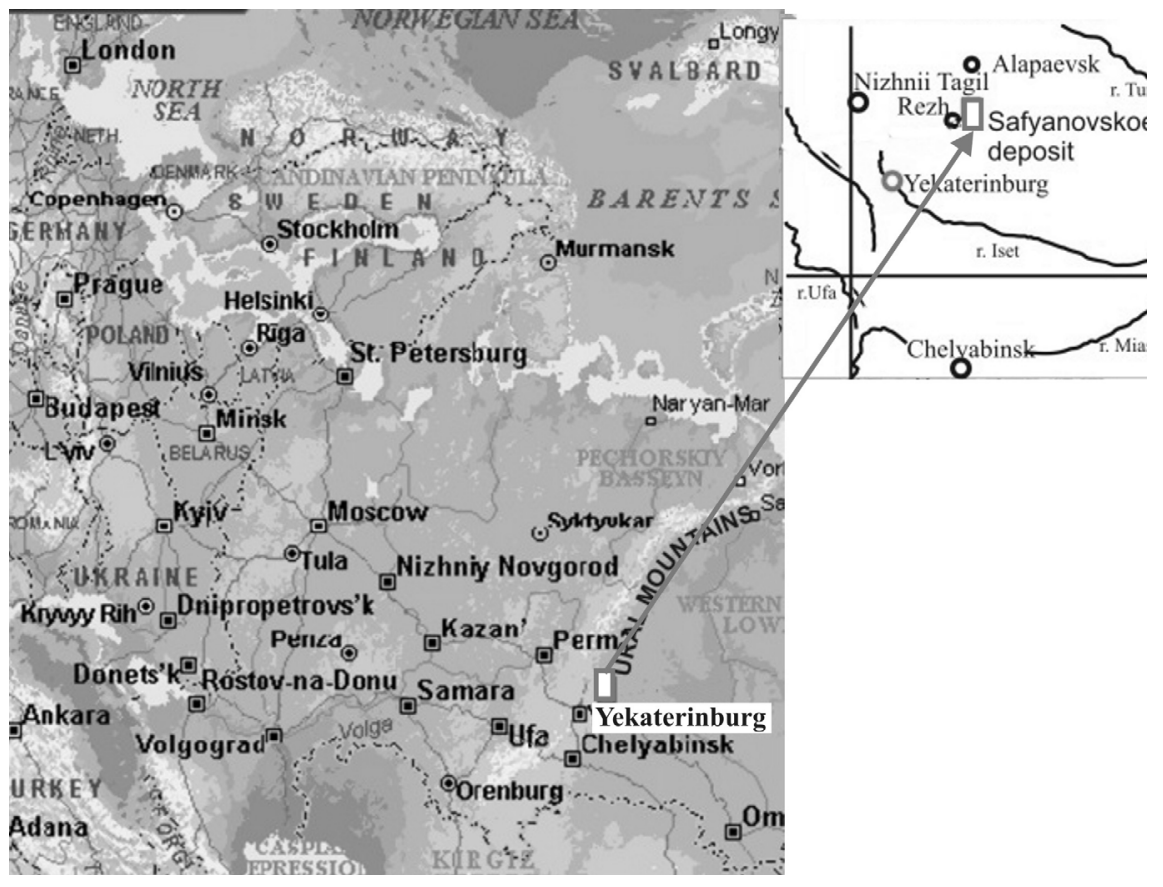

Figure 1. Map of the Safyanovskoe deposit's location.

Рисунок 1. Карта расположения Сафьяновского месторождения.

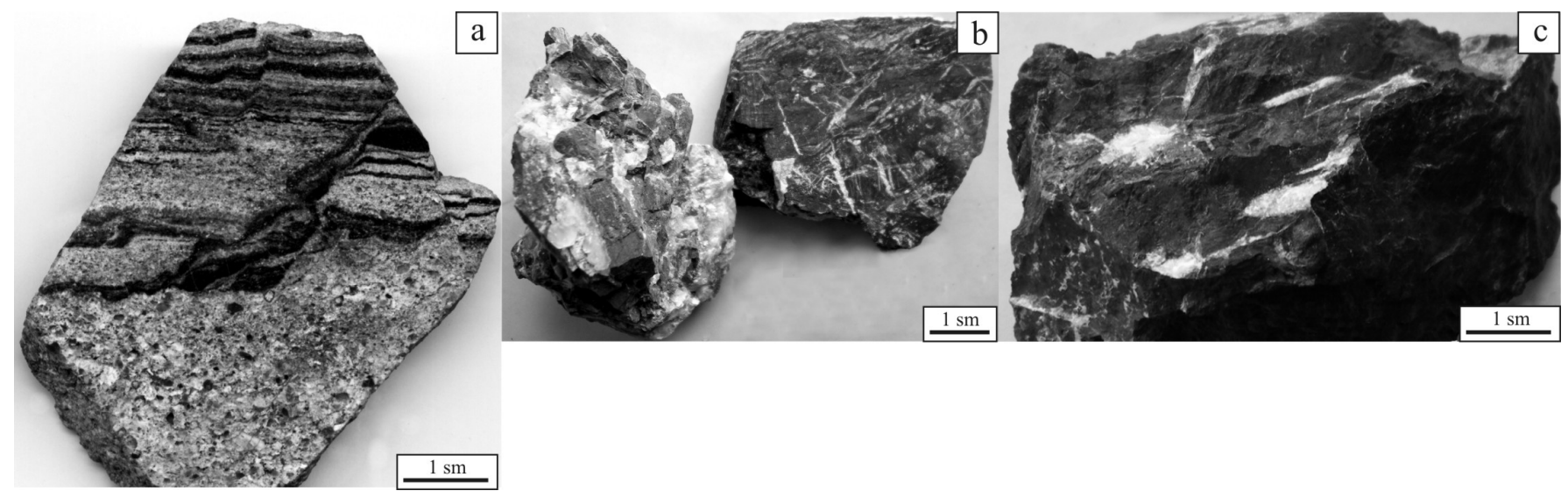

Figure 2. Carbon-bearing rocks of the Safyanovskoe deposit. a - contact of sandstones and siliceous-carbonaceous rocks in the Safyanovsky quarry, horizon $100 \mathrm{~m}$; b - limestone from the wall of the mine workings, $285 \mathrm{~m}$ depth; $\mathrm{c}$ - siliceous-carbonaceous rock from the wall of the mine workings, $285 \mathrm{~m}$ depth.

Рисунок 2. Углеродосодержащие породы Сафьяновского месторождения. а - контакт песчаников и кремнисто-углеродистых пород в Сафьяновском карьере, горизонт 100 м; b - известняк со стены горных выработок, глубина 285 м; с - кремнисто-углеродистая порода от стены горных выработок, глубина 285 м.

(southwestern flank of the Safyanovskoe ore field). Here they are in contact with Devonian amphipora bituminous limestone and serpentinite of the Rezhevsky massif.

Carbon-bearing-siliceous rocks are represented by psephite-psammitic tuffites, crystal-lithocrystalloclastic and pelitolitic. The structure consists of fragments of quartz, plagioclase crystals, angular-rounded fragments of rhyodacites, shells of foraminifera, radiolarians, and accumulations of carbon-bearing organic matter (COM), carbonates as well as chlorite, mica, kaolinite [3]. Sandstones are found in the ore-hosting mass of series and have virtually identical composition, graded bedding and, sometimes, wavy contacts with siliceous-carbonaceous rocks (Fig. 2, a).

Recent research on carbon-bearing-siliceous aleuropelites opened by quarry (horizons $157 \mathrm{~m}, 100 \mathrm{~m}$, rib-side count) have been found non-carbonate (apatite, quartz) shells of foraminifera Parathurammina aff. tamarae L. Petrova, 1981, the top Eifel-Givetian [4]. In the limestone (southwestern flank of deposit) opened by mine workings (d. $285 \mathrm{~m}$ ), have founded calcareous foraminifera Parathurammina magna Antropov, 1950 Eifel-Givetian [5], which confirmed the Middle Devonian age of volcanic-sedimentary rocks of ore-hosting strata.

The composition and characteristics of dispersed organic matter $(\mathrm{DOM})$ is an important indicator of rock facies and genesis of ore formation. With that in mind we have been studied carbon-bearing-siliceous rocks of ore-hosting strata of the Safyanovskoe copper-sulfide deposit (Middle Urals).

Materials and methods

Carbon-bearing siliceous rocks of the ore-hosting strata exposed by mine workings at the contact of limestone and 
serpentinites at depth of 285 m contain up to $4 \%$ organic bituminous matter. The mineral composition of the rocks is presented in Table 1. In 2013 in the wall of limestone mine were drilled two sub-horizontal wells No. 2340 and No. 2341 with length of $50 \mathrm{~m}$ towards the east and southeast. Limestone in the wall of mine is deep blue almost black color, fractured with crystals of calcite, dolomite, quartz and barite filling the cracks; contain sulfides and bituminous material (Fig. 2, b).

It was determined that in the south-east direction they taper out and grade to carbon-bearing-siliceous rocks (Fig. 2, c). Out of fault zone limestone are micro granular argillaceous-detrital broken by cracks with calcite and carbon-bearing-siliceous material. In a limestone it is observed that amphipora interlayer capacity of $0.1-0.2 \mathrm{~m}$ occurred through $0.5-1.0 \mathrm{~m}$. In order to determine the genesis of DOM we studied limestone opened by drift and carbon-bearing-siliceous rocks drift and quarry.

Carbon-siliceous formations are with carbon-bearing veinlet opened by mining, black and consist of quartz, chlorite, mica and plagioclase. There are impurities of calcite, magnesite, siderite, pyrite and COM in the rock matrix. They are identical on mineral composition to overlying formation rocks exposed by quarry. An earlier thermal analysis of the silica-carbonaceous rock samples, breccias and circum-ore metasomatites showed slightly metamorphosed organic matter (OM) of plant origin in amounts up to $6 \%$, which burns at $200-330^{\circ} \mathrm{C}[6]$ in studied samples.

The paramagnetic properties of the Safyanovskoe deposit rock containing DOM were studied by EPR (electron para- magnetic resonance). Spectra of paramagnetic carbon radicals are relatively simple and have been described for many solids and liquid natural $\mathrm{OM}$ as well as products of their thermochemical transformations.

Samples of carbon-bearing-siliceous rocks of quarry were studied in the Physics of minerals laboratory of KFU by A. A. Galeev and laboratory of physical and chemical test laboratory of the Institute of Geology and Geochemistry of the Ural Branch of the Russian Academy of Sciences (IGG UB RAS) by Yu. V. Shchapova. In the Physics of minerals laboratory of KFU EPR spectra were recorded from a powder weighed quantity of 20-40 mg of initial and heated samples at temperatures of 350 and $600{ }^{\circ} \mathrm{C}$ for 30 minutes. The recording was made at room temperature in the automatic mode on a DX-70 portable spectrometer with operating frequency 9.272 GHz. In the IGG UB RAS laboratory ESR spectra were recorded on spectrometer $70-03 \mathrm{DX} / 2$ at room temperature (initial test) and after samples heating up to 300 and $600{ }^{\circ} \mathrm{C}$ for $30 \mathrm{~min}$. Studies of limestone and carbon-bearing-siliceous rocks exposed by mine workings were carried out in the laboratory of mineralogy of the Institute of Geology of Komi Science Centre UB RAS by V. P. Lyutoev on X-band spectrometer SE/X-2547 RadioPAN. Recording mode is identical. The results are shown in table 2.

Modern geochemical studies at the reconstruction of facial-genetic conditions commonly use biomarker analysis. The amount of hydrocarbons (HC) in the composition of the DOM and their structural features serve to characterize

Table 1. The mineral composition of the carbon-bearing rocks of the Safyanovskoe deposit. Таблица 1. Минеральный состав углеродистых пород Сафьяновского месторождения.

\begin{tabular}{|c|c|c|}
\hline $\begin{array}{l}\text { Number } \\
\text { of sample }\end{array}$ & Name of rock, correlation & Mineral composition \\
\hline 1346 & Carbon-bearing rock, quarry, hor. 157 m (rib-side count) & $\begin{array}{l}\text { Quartz, plagioclase, hydromica, chloritic, brassil, barium } \\
\text { sulphate, OM 3,5\% }\end{array}$ \\
\hline D10/12 & Chalkstone, drift (D), dept. 285 m & Calcite, dolomite, barium sulphate \\
\hline $\mathrm{D} 11 / 12$ & Same & Same \\
\hline D12/12 & $\begin{array}{l}\text { Clinkstone, rock with clouded of calcite and sulphides, } \\
\text { hydrocarbons }\end{array}$ & $\begin{array}{l}\text { Plagioclase, chloritic, calcite, serpentine, derivatives of } \\
\text { sulphides }\end{array}$ \\
\hline $\mathrm{D} 13 / 12$ & $\begin{array}{l}\text { Flinty rock with clouded of calci-spar and sulphides, hydro- } \\
\text { carbons }\end{array}$ & $\begin{array}{l}\text { Quartz, magnesite, talc, serpentine, micaceous mineral, } \\
\text { derivatives of dolomite, calcite }\end{array}$ \\
\hline D14/12 & Same & $\begin{array}{l}\text { Quartz, talc, magnesite, derivatives of serpentine, calcite, } \\
\text { dolomite }\end{array}$ \\
\hline D15/12 & Same & Quartz, magnesite, talc, derivatives of calcite OM to $2-3 \%$ \\
\hline D16/12 & siliceous-carbonaceous rock & $\begin{array}{l}\text { Quartz, chloritic, glist, plagioclase, calcite, pyrite, } \\
\text { OM } 4 \%\end{array}$ \\
\hline D17/12 & Same & $\begin{array}{l}\text { Quartz, calcite, plagioclase, chloritic, glist, pyrite, deriva- } \\
\text { tives of magnesite, siderite }\end{array}$ \\
\hline D18/12 & Flinty rock with sulphides & Talc, quartz, magnesite, calcite, dolomite, serpentine, glist \\
\hline D19/12 & Clinkstone. serpentinite & $\begin{array}{l}\text { Serpentine mixed with chloritic, derivatives of talc, } \\
\text { amphibole }\end{array}$ \\
\hline D20/12 & Serpentinite & Serpentine, amphibole, magnetite \\
\hline D21/12 & Same & Same \\
\hline
\end{tabular}

Note. The mineral composition of the rocks is defined by X-ray phase analysis on diffractometer XRD-7000 (Shimadzu) (operator O. L. Galakhova), organic content determined by the thermal method (analyst V. G. Petrishcheva). Analyses are carried out in physical and chemical test laboratory of the Institute of Geology and Geochemistry of the Ural Branch of the Russian Academy of Sciences the city of Ekaterinburg. 
the genetic type of $\mathrm{OM}$ and its catagenetic transformation degree.

Earlier geochemical OM analysis of carbon-bearing-siliceous rocks of the Safyanovskoe deposit (height 157 m; quarry depth $50 \mathrm{~m}$ ) showed that it belongs to the sapropelic type [2]. We have recently carried out a geochemical OM study of rocks exposed by mine workings at a depth of $285 \mathrm{~m}$. The OM component composition is shown in Table 3.

The analytical procedure used in the OM study included determination of the rock insoluble residue and content $C_{\mathrm{org}}$, chloroform extract $\left(A_{\text {chl }}\right)$ and alcohol-benzene $\left(A_{\mathrm{alb}}\right)$ bitumens, humic acids (HA), determination of group composition of $A_{\mathrm{chl}}$

Table 2. Carbon Radicals in OM of the Safyanovskoe deposit.

Таблица 2. Углеводородные радикалы в органическом веществе Сафьяновского месторождения.

\begin{tabular}{|c|c|c|c|c|c|c|c|c|c|}
\hline \multirow{2}{*}{$\begin{array}{l}\text { Number } \\
\text { of sample }\end{array}$} & \multicolumn{3}{|c|}{ Untreated } & \multicolumn{3}{|c|}{ Annealing $300^{\circ} \mathrm{C}, 30 \mathrm{~min}$} & \multicolumn{3}{|c|}{ Annealing $600^{\circ} \mathrm{C}, 30 \mathrm{~min}$} \\
\hline & $g$-factor & $\Delta B, \mathrm{mT}$ & $C$, spins/g & $g$-factor & $\Delta B, \mathrm{mT}$ & $C$, spins/g & $g$-factor & $\Delta B, \mathrm{mT}$ & $C$, spins/g \\
\hline D10/12 & 2.0028 & 0.20 & $10^{16}$ & 2.0028 & 0.15 & $0.9 \cdot 10^{16}$ & 2.0028 & 0.23 & $10^{16}$ \\
\hline D11/12 & 2.0029 & 0.60 & $1.8 \cdot 10^{18}$ & 2.0032 & 0.70 & $2.6 \cdot 10^{18}$ & Not founded & - & - \\
\hline D15/12 & 2.0026 & 0.61 & $1.5 \cdot 10^{18}$ & 2.0029 & 0.67 & $2.0 \cdot 10^{18}$ & Not founded & - & - \\
\hline D16/12 & 2.0029 & 0.60 & $1.5 \cdot 10^{18}$ & 2.0032 & 0.70 & $1.3 \cdot 10^{18}$ & Not founded & - & - \\
\hline
\end{tabular}

Table 3. OM component composition of the Safyanovskoe deposit.

Таблица 3. Компонентный состав органического вещества Сафьяновского месторождения.

\begin{tabular}{|c|c|c|c|c|}
\hline \multirow{11}{*}{ Rock content, \% } & Component & L. K. IV-th & D14/12 & D16/12 \\
\hline & I. R. & 90.95 & & 89.93 \\
\hline & $\mathrm{CaCO}_{3}$ & 9.05 & & 10.07 \\
\hline & $\mathrm{C}_{\text {carb }}$ & 1.09 & & 1.21 \\
\hline & $\mathrm{C}_{\text {org }}$ in ir & 2.60 & & 3.77 \\
\hline & $\mathrm{C}_{\text {org }} /$ rock & 2.86 & & 4.19 \\
\hline & $\mathrm{OB}$ & 3.72 & & 5.45 \\
\hline & $A_{\mathrm{chl}}$ & 0.006 & 0.007 & 0.011 \\
\hline & $A_{\mathrm{alb}}$ & 0.010 & 0.003 & 0.004 \\
\hline & $\mathrm{HA}$ & 0.000 & & 0.000 \\
\hline & $\mathrm{CPI}$ & & 1.08 & 1.17 \\
\hline \multirow{4}{*}{ Group content OM, \% } & $A_{\mathrm{chl}}$ & 0.17 & 0.007 & 0.19 \\
\hline & $A_{\mathrm{alb}}$ & 0.27 & 0.003 & 0.07 \\
\hline & $\mathrm{HA}$ & 0.00 & & 0.00 \\
\hline & ROM & 99.6 & & 99.7 \\
\hline$\beta=\left(A_{\text {chl }} / C_{\text {org }}\right) \cdot 100$ & & 0.22 & & 0.25 \\
\hline$A_{\text {chl }} / A_{\text {alb }}$ & & & 2.3 & 2.9 \\
\hline \multirow{3}{*}{$A_{\mathrm{chl}}$ composition, \% } & Oils & 31.6 & 14.18 & 32.4 \\
\hline & Resins & 64.9 & 48.37 & 63.8 \\
\hline & Asphaltenes & 3.5 & 37.45 & 3.8 \\
\hline \multirow{2}{*}{$\mathrm{HC}, \%$} & In rock & 0.002 & & 0.003 \\
\hline & In OM & 0.05 & & 0.06 \\
\hline \multirow{2}{*}{ HC composition, \% } & $\mathrm{Me}-\mathrm{Nf}$ & 58.8 & & 72.7 \\
\hline & $\mathrm{Ar}$ & 41.2 & & 27.3 \\
\hline $\mathrm{Me}-\mathrm{Nf} / \mathrm{Ar}$ & & 1.42 & & 2.7 \\
\hline Me-Nf, \% & In rock & 0.0013 & & 0.0025 \\
\hline $\mathrm{Ar}, \%$ & In rock & 0.0008 & & 0.0009 \\
\hline $\mathrm{C}_{17} / \mathrm{C}_{27}$ & & & 24.4 & 10.88 \\
\hline $\mathrm{Pr} / \mathrm{Ph}$ & In rock & & 0.87 & 0.96 \\
\hline $\mathrm{Pr} / \mathrm{C}_{17}$ & In rock & & 0.62 & 0.45 \\
\hline $\mathrm{Ph} / \mathrm{C}_{18}$ & In rock & & 0.88 & 0.96 \\
\hline $\mathrm{Ts} / \mathrm{Ts}+\mathrm{Tm}$ & In rock & & & 0.51 \\
\hline $22 S / 22 S+22 R$ & In rock & & & 0.60 \\
\hline $20 S /(S+R)$ & In rock & & & 0.38 \\
\hline$S$ & In rock & & & 0.45 \\
\hline
\end{tabular}

Note: I. R. (ir) - insoluble residue; $A_{\text {hl }}$ - chloroform bitumoid; $A_{\text {ab }}$ - alcohol-benzene bitumoid; HA - humic acid; $\beta$ - bituminosity coefficient; $\mathrm{HC}$ - hydrocarbons; Me-Nf - methane-naphthenic fractions of hydrocarbons; Ar - aromatic hydrocarbon fraction; ROM (residuel organic matter) - degree of polymerization; CPI - oddity coefficient. Weighed quantity of sample D16/12 to $104.5 \mathrm{~g}$ sample weight D14/12 100 g. Sample data L.K. IV-th of the Safyanovsky quarry is given according to citation 2 [2]. 


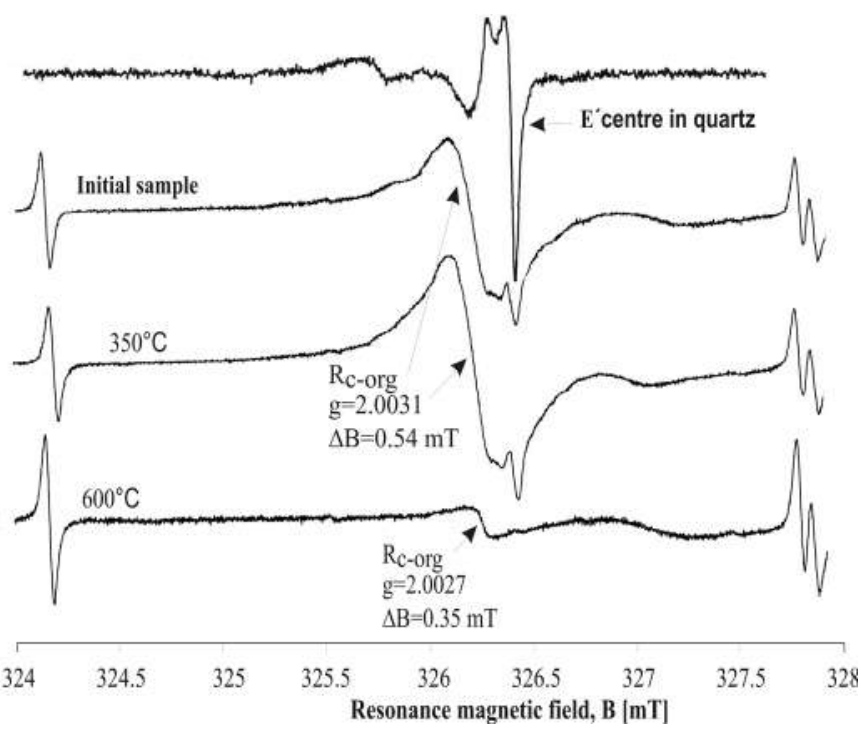

Figure 3. Characteristic EPR spectra in the resonance magnetic field region of thermally unstable $O M$ and quartz radicals.

Рисунок 3. Характеристические спектры ЭПР в области резонансного магнитного поля термически нестабильных радикалов органического вещества и кварца.

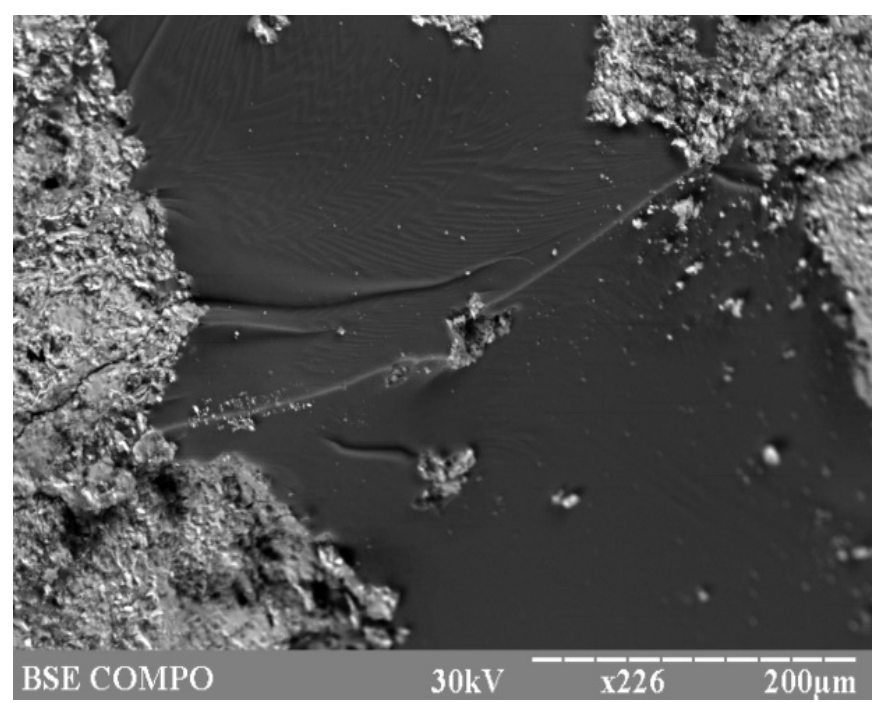

Figure 4. Scanning electron microscopic images of carbonaceous streaks in siliceous-carbonaceous rock of the Safyanovskoe deposit.

Рисунок 4. Сканирующее электронно-микроскопическое изображение углеродистой полосы в кремнисто-углеродистой породе Сафьяновского месторождения.

and hydrocarbons (HC), chromatographic fractionation with the extract of the methanol-naphthenic and aromatic fractions of hydrocarbons, GC-MS analysis of n-alkanes, cyclic and polyaromatic hydrocarbons (PAH). GC-MS analysis of the samples SH16/12 was performed on the complex Hewlett Packard 6850/5973 with a quadrupole mass detector and analytical information processing software at the All-Union Research Institute of Oceanology, Department of Oil and Gas Potential of the Arctic and Oceans, Laboratory of Organic Geochemistry, in the city of St. Petersburg, by the analyst V. I. Petrova. Sample SH14/12 was examined in the laboratory of Geochemistry of Combustible Minerals, Department of
Petroleum Geology KFU, in the city of Kazan, by the analyst F. F. Nosova.

\section{Results and discussion}

Fig. 3 shows the typical ESR spectra of carbon-bearing-siliceous rocks from the Safyanovskoe deposit quarry. Analysis of the spectra showed the presence of two types of signal $\mathrm{C}_{\mathrm{org}}$ specific to plant and animal remains [7]. The spectra, as in the initial samples as well as after heating at $300^{\circ} \mathrm{C}$, reveals a signal in the $\mathrm{C}_{\text {org }}$ area with a broad spectrum line (Fig. 4). The signal characteristics after annealing at $300{ }^{\circ} \mathrm{C}: \mathrm{g} \sim 2,0031 \pm 0.0001$ and line width $\Delta B \sim 0.5-0.7 \mathrm{mT}$, indicating the presence of $\mathrm{OM}$ plant residues metamorphosed at relatively low-temperature conditions (not exceeding $300{ }^{\circ} \mathrm{C}$ ) [8]. Once heated to $600{ }^{\circ} \mathrm{C}$ $\mathrm{C}_{\text {org }}$, a signal with $g \sim 2.0027 \pm 0.0001$ appeared as a narrow spectrum line $(\Delta B=0.15-0.2 \mathrm{mT})$. The signals from these parameters are peculiar to the OM remains of protein series [7]. Perhaps, this OM formed as a result of spoilage microorganisms on the stage of sedimentation and early diagenesis.

Analysis of the EPR spectra of DOM rocks exposed by mining revealed its identity to quarry samples. It was metamorphosed under temperature not higher than $300^{\circ} \mathrm{C}$ (Table 2). A sample of limestone $\mathrm{SH} 10 / 12$ revealed two types of signals $\mathrm{C}_{\text {org }}$, which may indicate similar depositional conditions for carbon-bearing-siliceous formations as well as limestone. Judging by the intensity of the spectrum in sample 1346 of quarry [6] and SH16/12 (Table 2) carbon-bearing-siliceous rocks, the concentration of paramagnetic centers $\mathrm{C}_{\text {org }}-1.3$. $10^{18} \mathrm{spin} / \mathrm{g}$, and in samples of limestone SH11/12 - 2,6 $610^{18}$ (Table 2), which is typical of some types of coal [8]. Scanning electron microscopic images of carbonaceous streaks in siliceous-carbonaceous rock obtained using a REMMA-202M microscope (operator E. V. Nuzhdin) show a structurally uniform black surface with a shell fracture, which may be characteristic of vitrinite (Fig. 4). It can be assumed that the carbonaceous material was at a low (brownish) stage of metamorphism and is now represented by fusenized (inertinite) and vitrenized (gelified) plant residues as well as soluble compounds that were originally part of the lipoid microcomponents of resins.

In addition, in the spectra of carbon-bearing-siliceous rocks (SH16/12 and 1346) the signal $E^{\prime}$ in the center of quartz are observed (Fig. 3). Preservation of this center throughout the history of rocks also indicated the low-temperature transformation of the rock. Additional centers were identified in the EPR spectra of limestone (sample $\mathrm{SH} 10 / 12)$ : center $\mathrm{SO}_{2}-(\mathrm{g}=$ $2,005)$ and axial $\mathrm{CO}_{2}-(\mathrm{g}=1,999 ; 2,003)$, which indicates the low temperature effects on limestone not exceeding $250^{\circ} \mathrm{C}$.

The EPR spectrum of the sample SH15/12 $(\mathrm{g}=2.0026$, Table 2) is typical for OM series of bitumen, which $g$-factor value can be attributed to oxykerit with the line width and the presence of a weak signal after heating at $600{ }^{\circ} \mathrm{C}$. Except for the value of the $g$-factor, oxykerites similar to some shungites of Karelia $(g=2,0024)[9])$, which are on the regressive stage of metamorphism.

As a result of chemical analysis OM of carbon-bearing-siliceous rocks of the Safyanovskoe deposit it was found that in spite of a fairly high content of $\mathrm{C}_{\text {org }}(4.19 \%)$ and chloroform bitumoid $\left(A_{\mathrm{chl}}=0.011 \%\right), \mathrm{DOM}$ is at the advanced stage of transformation $(\mathrm{ROM}>99 \%)[10]$. This is consistent with the absence of humic acid. The composition of the soluble DOM components is dominated by non-oxidized structures $\left(A_{\mathrm{chl}} /\right.$ 


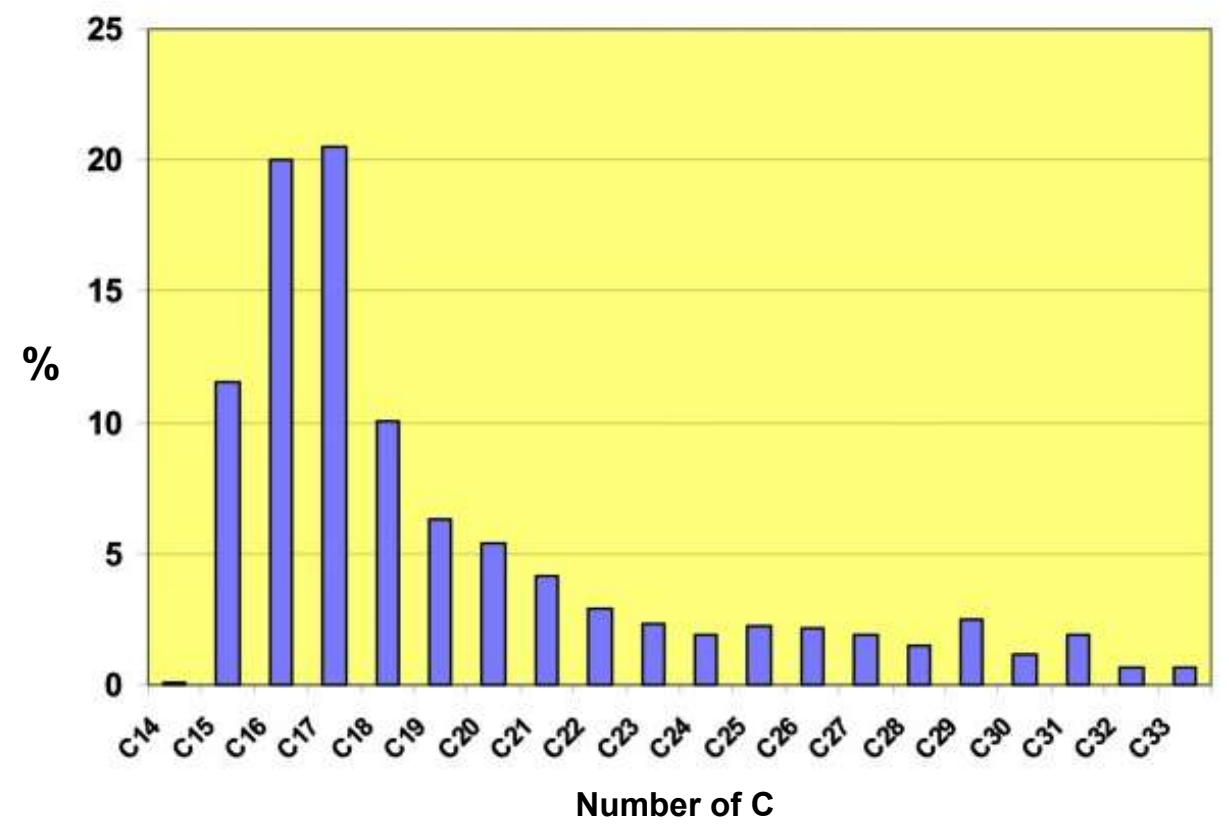

Figure 5. Carbon number distribution of $n$-alkanes in carbonaceous-siliceous rocks from the Safyanovskoe field.

Рисунок 5. Распределение углеродных чисел н-алканов в углисто-кремнистых породах Сафьяновского месторождения.

Table 4. The relative content and terpanes in the sample D16/12.

Таблица 4. Относительное содержание терпанов в пробе D16 / 12.

\begin{tabular}{|c|c|c|c|c|c|}
\hline \multicolumn{3}{|c|}{ Triterpanes } & \multicolumn{3}{|c|}{ Steranes } \\
\hline $\mathrm{C}_{19-20} T_{\text {ric }} / \mathrm{C}_{23-26}$ & 0,70 & $<1$ marine & Percent of the amount of steranes & & \\
\hline $\mathrm{C}_{23-26} T_{\text {ric }} / \mathrm{C}_{28-31}$ & 3,45 & 1 marine & $\mathrm{C}_{27}$ & 39,5 & $>33 \%$ marine \\
\hline $\mathrm{H}_{29} / \mathrm{H}_{30}$ & 0,77 & $>0,60$ marine & $\mathrm{C}_{28}$ & 22,2 & \\
\hline $\mathrm{H}_{31} \mathrm{R} / \mathrm{H}_{30}$ & 0,34 & $>0,25$ marine & $\mathrm{C}_{29}$ & 38,3 & \\
\hline $\mathrm{H}_{35} \mathrm{R} / \mathrm{H}_{34} \mathrm{R}$ & $\mathrm{Nd} \mathrm{H}_{35} \mathrm{R}$ & & $27(a b b+a a a) / 29(a b b+a a a)$ & 1,03 & $>0,9$ marine \\
\hline${ }_{29} T s /\left({ }_{29} T s+C_{29}\right)$ & 0,25 & & $28(a b b+a a a) / 29(a b b+a a a)$ & 0,58 & $>0,7$ marine \\
\hline $\mathrm{Ts} / \mathrm{Ts}+\mathrm{Tm}$ & 0,51 & 1,0 equilibrium & dia/reg $\left(\mathrm{C}_{27}\right)$ & 0,40 & 1,0 equilibrium \\
\hline $\mathrm{C}_{31} \alpha \beta\left({ }_{22} \mathrm{~S} /{ }_{22} \mathrm{~S}+{ }_{22} \mathrm{R}\right)$ & 0,60 & 0,62 equilibrium & ${ }_{20} \mathrm{~S} /(\mathrm{S}+\mathrm{R}) \alpha \alpha \alpha \mathrm{C}_{29}$ & 0,38 & 0,55 equilibrium \\
\hline$C_{30} \beta \alpha /(\alpha \beta+\beta \alpha)$ & Nd moretane & & $C_{29} \alpha \beta \beta /(\alpha \beta \beta+\alpha \alpha \alpha)(S)$ & 0,45 & 0,70 equilibrium \\
\hline
\end{tabular}

Note: $\mathrm{nd}^{*}$-components is absent or is below the detection threshold; $\mathrm{C}_{27}-\mathrm{C}_{35}$ - hopanes; $\mathrm{S}, \mathrm{R}$ - enantiomers of $\mathrm{C}_{27}-\mathrm{C}_{35}$ hopanes;

Ts-18a trisnorneogopan $\left(\mathrm{C}_{27}\right)$; Tm-17a trisnorgopan $\left(\mathrm{C}_{27}\right)[12]$.

Polyaromatic hydrocarbons. The distribution of PAHs is shown in Fig. 5. Based on the above data, a feature of the test sample is a high content of PAH. As part of the aromatic hydrocarbons fraction they represent approximately $65 \%$ (MPI - 0.40 - transformation level index of non-substituted phenanthrene and its methyl homologues; $\mathrm{Fl} / 202-0.25$ fluoranthene share in the total content of molecular group 202).

$\left.A_{\text {alb }}=2.9\right)$, and the value of $\beta(0.25)$ is much lower than 1 (Table 3), which indicates synergetic nature OM. It is known that $\beta$ - is the main indicator at the identification of the genetic type bitumoid its sinergeticity or epigeneticity in relation to the host rocks. In the case of syngenetic bitumoid its value does not exceed 5-10 [11].

The hydrocarbon content of COM and OM in the rock is relatively low, but in their group composition dominates aliphatic compounds.
Normal alkanes and isoprenoids. Paraffin hydrocarbons are genetic markers that allow determining the origin of the initial organic material. The parameters characterizing the distribution of hydrocarbon alkane series $\left(\mathrm{C}_{17-19}\right)$ and $\left(\mathrm{C}_{27-31}\right)$ make it possible to indicate the fraction of aquatic and terrigenous biota in the formation of OM bottom sediment [12]. The molecular structure of $n$-alkanes and isoprenoids shows mostly hydrobionts genesis of the original $\mathrm{OM}$, as indicated by the ratio of the markers of sapropel and humic compounds 


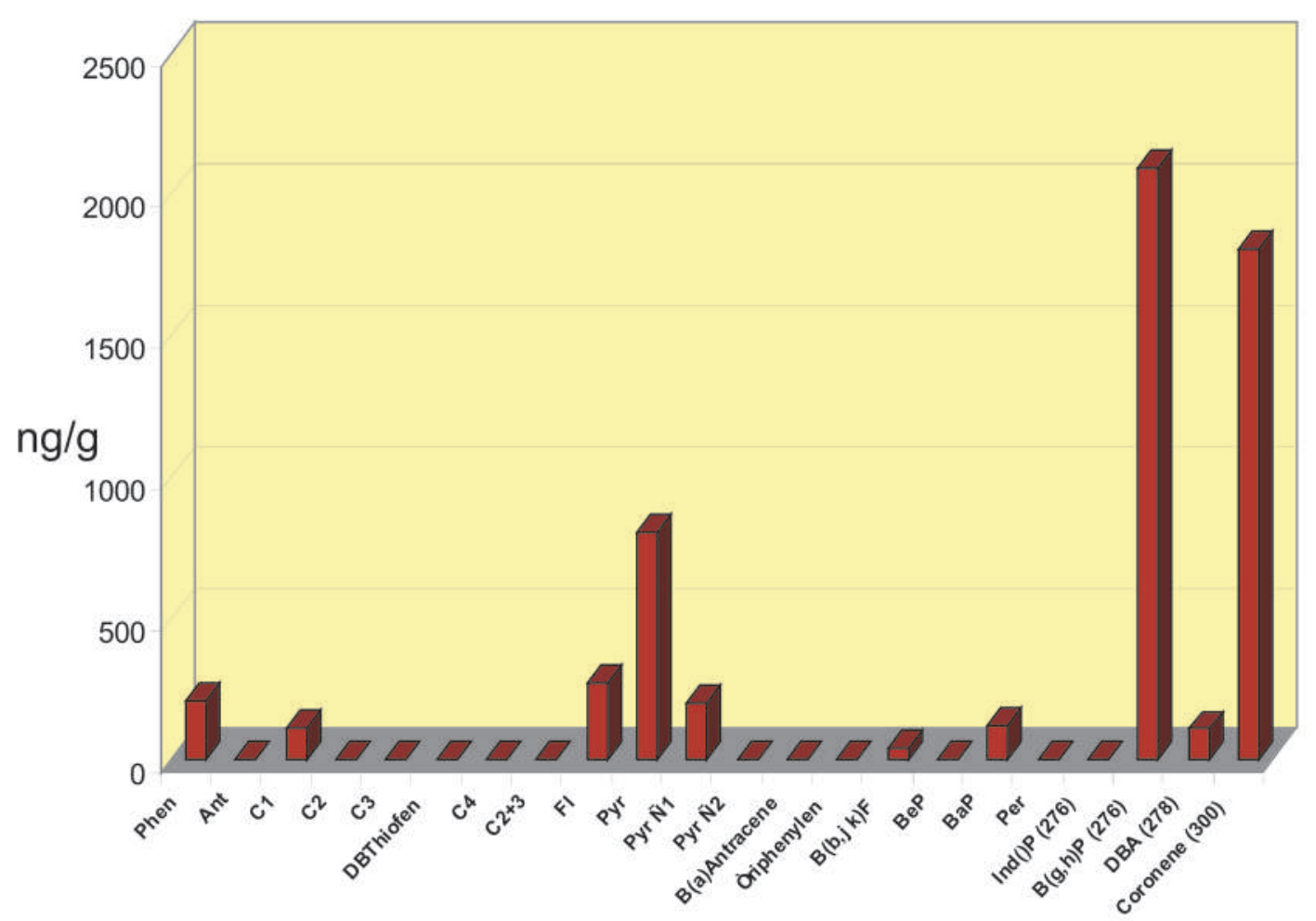

Figure 6. Distribution of polyaromatic hydrocarbons (PAH) in carbonaceous-siliceous rocks from the Safyanovskoe deposit. Рисунок 6. Распределение полиароматических углеводородов (ПАУ) в углисто-кремнистых породах Сафьяновского месторождения.

$\left(\mathrm{C}_{17} / \mathrm{C}_{29}=10.88\right)$ as well as the mono-modal nature of the $\mathrm{n}$-alkanes distribution with the overwhelming dominance of low molecular weight compounds $\left(\mathrm{C}_{15-19}\right)$ (Fig. 5). The oddity coefficient CPI, close to 1 indicates the high degree of n-alkanes conversion and $\mathrm{OM}$ as a whole. Isoprenoids pristane and phytane ratio $\left(\mathrm{Pr} / \mathrm{Ph}<2\right.$ and $\left.\mathrm{Pr} / \mathrm{C}_{17}=0.45\right)$ is typical for marine deposition of sediments $[12,13]$.

Terpanes and steranes. Distribution of cyclane hydrocarbons (terpanes, hopanes, cyclanes) in the studied sample also indicates mainly sapropelic genesis of OM. This is evidenced by the value of tricyclanes coefficients $\left(\mathrm{C}_{19-20} T_{\text {ric }}\right.$ l $\left.\mathrm{C}_{23-26} ; \mathrm{C}_{23-26} T_{\text {ric }} / \mathrm{C}_{28-31}\right)$ and the ratio of norgopan, hopane and $\mathrm{C}_{31}$ - homohopane that can serve as indicators of the origin of the initial organic material [14]. A data presented in Table 4 clearly demonstrate the significant role of the "sea" hydrobiont $\mathrm{OM}$ in the original organic material.

In the geological objects hopanes are present in the form of homologous series of compounds of $\mathrm{C}_{27}-\mathrm{C}_{35}$. At the stage of sedimentogenesis and early diagenesis, biogenic hopanes ( $\beta \beta$-hopanes) are formed, at the postdiagenetic stage, take the structural transformation of hopanes occurs with formation $\alpha \beta$ - and $\beta \alpha$-hopanes. For hopanes of composition of $\mathrm{C}_{31}-\mathrm{C}_{35}$, enantiomers of the configuration $\mathrm{R}$ in $\mathrm{S}$ are isomerized. $\mathrm{Ab}$ sence in the composition of terpanes, biohopanes and moretanes ( $\beta \beta$ - and $\beta \alpha$-isomers) indicates the postdiagenetic transformation of DOM. At the same time the ambiguity of hopanes maturity level of DOM (Ts/Ts $\left.+\mathrm{Tm},{ }_{22} \mathrm{~S} /{ }_{22} \mathrm{~S}+{ }_{22} \mathrm{RC}_{31}\right)$ does not allow to characterize the maturity levels of DOM as reached the thermodynamic limit. . This assumption is also supported by the distribution of sterans (Table 4), whose maturity indices are far from thermodynamic limit and do not exceed the values characteristic of the early stage katagenesis $\left(\mathrm{MK}_{1}\right)$.
In a homologous series of steranes $\left(\mathrm{C}_{27}-\mathrm{C}_{30}\right)$ dominated cholestanes $\left(\mathrm{C}_{27}\right)$, which reflect the contribution of aquatic organisms in the composition of initial OM. The ratios of regular and rearranged isomers in the homologous series of steranes are also aimed at determining the genetic type of the initial DOM. These data compare favorably with the above mentioned values for alkanes and terpanes.

Unlike conventional sedimentary rocks [12], PAHs are dominated by unsubstituted condensed polyaromatic compounds with four to seven rings (MM 178, 202, 228, 252, 276, 278). Thus the pyrogenic compound, the formation of which is associated with a high impact on the DOM, constitutes $94 \%$ of the PAH amount (Fig. 6). Naphthidogenic PAH are typical of sedimentary rocks, being formed by the transformation of DOM during lithogenesis. However, in this case it is a minor component. This type of PAH distribution suggests that initial OM undergone specific transformation under high temperatures.

As a result of geochemical researches it can be concluded that the OM carbon-bearing-siliceous rocks of the Safyanovskoe deposits genetically the same type, mainly sapropel and its accumulation is due to sea conditions. A characteristic feature is, on the one hand, its polymerization, which is typical for the DOM of the stage of late mesokatagenesis. On the other hand, its molecular structure cannot be indicative of the maturation of DOM during natural regional metamorphism. The specifics of the geochemical parameters of DOM can be due, for example, to the effect of high temperatures associated with the intrusive processes (contact metamorphism) or post volcanic hydrothermal activity.

As noted above, in some physical and chemical parameters (sample D 15/12, Table 2), OM of the Safyanovskoe 
field can be compared to OM of Karelia shungites. According to geochemical characteristics of OM carbon-bearing-siliceous rocks Safyanovskoe deposits (Table 3), it is comparable to low-carbon shungite deposits of Shunga $\left(\mathrm{C}_{\mathrm{org}}-3 \% ; A_{\mathrm{chl}}-\right.$ 0.017, $A_{\text {alb }}-0.01 ; \mathrm{Pr} / \mathrm{Ph}-0.78 ; \mathrm{Ts} / \mathrm{Ts}+\mathrm{Tm}-0.42-0.76 ;{ }_{22} \mathrm{~S}$ ${ }_{22} \mathrm{~S}+{ }_{22} \mathrm{R}-0.39-0.49$, with a low fraction of moretanes [15]). Temperature of metamorphism of Shungovskoe deposit is estimated at $300-330{ }^{\circ} \mathrm{C}[16]$. However, unlike shungites, the $\mathrm{HC}$ of the Safyanovskoe massive sulfide deposit contains aromatic compounds with a high content of $\mathrm{PAH}$, which means a lower degree of metamorphic transformation.

A geochemical study of OM of modern sulfide hydrothermal sediments of the Mid-Atlantic Ridge (i. e., in the Ashadze, Lost City, Rainbow and Broken Spur fields) showed its mixed genesis, the specificity of which is due to accelerated OM maturation processes under extreme environmental conditions $[17,18]$. Pyrogenic compounds in $\mathrm{PAH}$ composition were identified in the OM bottom sediments within the Ashadze-1 hydrothermal field [17]. This pyrolytic component is a narrow range of compounds $(\mathrm{Fl} / 202-0.7)$. Given the presence in the composition of cyclanes, cheilanthanes, diasteranes and geogopanes as sufficiently pyrogenic indicators of aromatic hydrocarbons, being indicators of the maturity level of the n-alkanes substance (CPI-1), the authors [7] concluded that the accelerated thermal catalytic maturation of $\mathrm{OM}$ in sediments of the Ashadze-1 field under the influence of the hydrothermal conditions of the environment was "expressed in the seal and the polycondensation of geochemically less stable structures."

Hydrocarbon distribution in the bottom sediments of the hydrothermal fields of Lost City and Rainbow (MAC) is char- acterized by the presence of even-numbered homologues in the low- and high-molecular-weight portions of the area, as reflected in the CPI parameter values, which average 0.86 and 0.89 , respectively [19]. This is a result of reduction processes that have occurred in the hydrothermal transformation of OM. Moreover, in the sulfide sediments of the Rainbow and Broken Spur fields there are n-alkanes of abiogenically thermo-origin and sediments of active smokers characterized by high levels of long-chain n-alkanes $\Sigma \mathrm{C}_{23}-\mathrm{C}_{35}-85.7 \%$ [18].

According to data from our research, the OM of the Safyanovskoe deposit was exposed to the low temperature - not higher than $300{ }^{\circ} \mathrm{C}$. Since, according to the EPR data, it presedved paramagnetic tracers of plant and animal origin (Sample SH10/12, Table 2), as well as radiation centers in minerals, for some samples, in particular, limestone, temperature exposure limit was not higher than $250^{\circ} \mathrm{C}$. Given the data [20] on the forming conditions of barite veins in the formation of ore facies of the Safyanovskoe deposit as well as in the formation temperature of chlorite wall rock [21], we can assume that the temperature range of wall-rock alteration, in the presence of rocks containing OM, ranges from $130^{\circ}$ to $260^{\circ} \mathrm{C}$.

\section{Conclusion}

The geochemical study of OM in the rocks of the Safyanovskoe deposit confirmed its affiliation to the sapropel type and sea-shallow formation conditions. According to the geochemical and physicochemical study of OM, its syngeneticity with enclosing wall rocks was established. The level of OM transformation of the Safyanovskoe deposit indicates its rapid (albeit incomplete) maturation during the evolution of the hydrothermal fluid.

The work was carried out within the framework of the state task of the Zavaritsky Institute of Geology and Geochemistry of the Ural Branch of the Russian Academy of Sciences (State registration No. AAAA-A18-118052590028-9).

The authors thank the chief geologist N. V. Leshchev and the team of "Safyanmed" JSC for the provision of materials for the paper. Our study was prepared with partial support from subsidy funds allocated within the framework of the state support of Kazan (Volga) Federal University in order to improve its competitiveness among the world's leading scientific and educational centers, as well as a grant from Kazan Federal University to carry out public tasks in the field of scientific activity.

\section{REFERENCES}

1. Yazeva R. G., Moloshag V. P., Bochkarev V. V. Geologiya Safiyanovskogo kolchedannogo mestorozhdeniya (Srednii Ural). Preprint. Ekaterinburg: UrO RAN, 1992. $71 \mathrm{p}$.

2. Yaroslavtseva N. S., Maslennikov V. V., Safina N. P., Leschov N. V., Soroka E. I. Uglerodsoderzhashie alevropelity Safiyanovskogo Cu-Znkolchedannogo mestorozhdeniya (Srednii Ural) // Litosfera. 2012. № 2. P. 106-123.

3. Anfimov A. L., Soroka E. I., Yaroslavtseva N. S., Glavatskikh S. P. Genezis uglerodisto-kremnistykh prosloev v rudovmeschayuschei vulcanogenno-osadochnoi tolsche Safiyanovskogo Cu-kolchedannogo mestorozhdeniya (Srednii Ural) // Vulcanizm i geodinamica. V Vseros. Simpos. po vulcan. i paleovulcan. Ekaterinburg: IGG UrO RAN, 2011. P. 474-476.

4. Chuvashov B. I., Anfimov A. L., Soroka E. I., Yaroslavtseva N. S. Novye dannye o vozraste rudovmeschayuschei tolschi Safiyanovskogo mestorozhdeniya (Srednii Ural) na osnove foraminifer // DAN. 2011. T. 439, № 5. P. 648-650.

5. Chuvashov B. I., Anfimov A. L., Soroka E. I., Yaroslavtseva N. S. Devonskiye foraminifery s nekarbonatnoi rakovinoi v rudovmeschayuschei tolsche Safiyanovskogo mestorozhdeniya (Srednii Ural) // Litosfera. 2012. № 5. P. 114-126.

6. Soroka E. I., Moloshag V. P., Leonova L. V., Petrischeva V. G., Yaroslavtseva N. S. Kremnisto-uglerodistye otlozheniya rudovmeschayuschei tolschi Safiyanovskogo Cu-kolchedannogo mestorozhdeniya (Srednii Ural) // Ezhegodnik-2009. IGG UrO RAN. 2010. P. $250-254$.

7. Muraviev. F. A., Vinokurov V. M., Galeev A. A., Bulka G. R., Nizamutdinov V. M., Khasanova N. M. Paramagnetizm i priroda rasseyannogo organicheskogo veschestva v permskhikh otlozheniyakh Tatarstana // Georesursy. 2006. № 2 (19). P. 40-45.

8. Khasanov R. R., Galeev A. A. Mineraloobrazuyuschaya rol zakhoronennykh rastitelnykh ostatkov $\vee$ protsesse gidrogennogo mednogo rudogeneza // Izv. vuzov. Geologiya i razvedka. 2004. № 1. P. 18-22.

9. Galeev A. A., Filippov M. M. Priroda defectov molekulyarnoi structury vysshykh antraksolitov po dannym EPR-spectroskopii // Geologiya i poleznye iskopaemye Karelii. 2005. Vyp. 8. P. 121-127.

10. Neruchev S. G. Spravochnik po geokhimii nefti i gaza. SPb.: OAO Nedra, 1998. 576 p.

11. Korchagina Yu. I., Chetvericova O. P. Metody issledovaniya rasseyannogo organicheskogo veschestva osadochnykh porod. M.: Nedra, 1976.230 p.

12. Petrova V. I., Batova G. I., Kursheva A. B. i dr. Organicheskoe veschestvo donnykh osadkov Obskoi guby: raspredelenie, priroda, istochniki // Geokhimiya. 2010. № 2. P. 1-13.

13. Romankevich E. A. Geokhimiya organicheskogo veschestva v okeane. M.: Nauka, 1977. 256 p.

14. Kostyreva E. A. Geokhimiya i genezis paleozoiskhikh neftei yugo-vostoka Zapadnoi Sibiri. Novosibirsk: Izd-vo SO RAN, «Geo», 2005. 183 p.

15. Shanina S. N., Golubev E. A., Burdelnaya N. S. Uglevodorody-biomarkery v shyungitakh Karelii // Geokhimiya. 2013. № 9. P. $842-848$.

16. Filippov M. M. Shungitonosnye porody Onezhskoi structury. Petrozavodsk: Karelskii NTsRAN, 2002. 280 p. 
17. Morgunova I. P., Ivanov V. N., Litvinenko I. V., Petrova V. I., Stepanova T. V., Cherkashov G. A. Geokhimiya organicheskogo veschestva donnykh otlozhenii gidrotermalnogo polya Ashadze (13º s.sh., Sredinno-Atlanticheskii khrebet) // Okeanologiya. 2012. T. 52, № 3. P. 372-380.

18. Shulga N. A., Peresypkin V. I., Revelskii I. A. Izuchenie i sostav n-alkanov v obraztsakh gidrotermalnykh otlozhenii Sredinno-Atlanticheskogo khrebeta s pomoschyu metoda gazovoi khromatografii/mass-spectrometrii // Okeanologiya. 2010. T. 50, № 4. P. 515-523.

19. Shulga N. A., Peresypkin V. I. O genezise uglevodorodov polei Lost Siti i Reinbou (Sredinno-Atlanticheskii khrebet) // DAN. 2012. T. 445, № 2. P. $196-199$.

20. Safina N. P., Ankusheva N. N., Murzin V. V. Fiziko-khimicheskie usloviya formirovaniya barita iz rudnykh fatsii Safiyanovskogo Cu-Znkolchedannogo mestorozhdeniya (Srednii Ural) // Litosfera. 2012. № 3. P. 110-126.

21. Soroka E. I., Moloshag V. P., Filippov V. N., Galakhova O. L., Pritchin M. E. Khlorit iz okolorudnykh vulkanogennykh porod Safiyanovskogo mestorozhdeniya // XIII Vserossiiskie nauchnye chteniya pamyati V. O. Polyakova. Miass, 2012. P. 67-73.

The article was received on Desember 10, 2019 


\title{
Особенности органического вешества как индикатора степени изменения пород Сасьяновского медноколчеданного месторождения (Средний Ураи)
}

\author{
Елена Индустровна СОРОКА ${ }^{1 *}$, \\ Ахмет Асхатович ГАЛЕЕВ ${ }^{2}$, \\ Вера Игоревна ПЕТРОВА ${ }^{3}$, \\ Владимир Павлович ЛЮТОЕВ ${ }^{3}$, \\ Любовь Владимировна ЛЕОНОВА $4^{* \star}$ \\ ${ }^{1}$ Институт геологии и геохимии им. академика А. Н. Заварицкого УрО РАН, Россия, Екатеринбург \\ ${ }^{2}$ Казанский (Приволжский) федеральный университет, Институт геологии и нефтегазовых технологий, \\ Россия, Казань \\ ${ }^{3}$ ВНИИОкеангеология, Россия, Санкт-Петербург \\ ${ }^{4}$ Институт геологии Коми научного центра УрО РАН, Россия, Сыктывкар
}

Аннотация

Актуальность работь заключается в том, что рассеянное органическое вещество (РОВ) является важным индикатором фациальной принадлежности пород, что может способствовать палеоэкологической реконструкции условий седиментации пород рудовмещающей толщи Сафьяновского месторождения (Средний Урал).

Цель работы: исследование состава и особенностей РОВ углеродисто-кремнистых пород рудовмещающей толщи Сафьяновского медноколчеданного месторождения. Полученные характеристики РОВ позволяют выявить источники его поступления и уровень трансформации под воздействием различных геологических процессов.

Методология исследований. Детальное изучение РОВ проводилось методом ЭПР (электронного парамагнитного резонанса). Запись спектров производилась при комнатной температуре в автоматическом режиме на портативном спектрометре DX-70 с рабочей частотой 9,272 ГГц, на спектрометре ESR 70-03 DX/2 и на радиоспектрометре X-диапазона SE/X-2547 RadioPAN. Аналитическая процедура изучения органического вещества (OB) включала: определение в породе нерастворимого остатка и содержания С хлороформного $A_{\text {хл }}$ и спиртобензольного $A_{\text {сп-б }}$ битумоидов, гуминовых кислот (ГК), определение группового

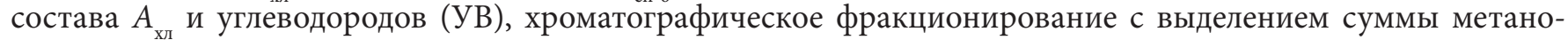
нафтеновой и ароматической фракций УВ, ГХ-МС анализ н-алканов, циклических и полиароматических углеводородов (ПАУ). ГХ-МС анализ проводили на комплексе Hewlett Packard 6850/5973 с квадрупольным масс-детектором и программным комплексом обработки аналитической информации.

Результаты. Анализ спектров ЭПР углеродисто-кремнистых пород Сафьяновского месторождения показал наличие двух типов сигнала углерода $\mathrm{C}_{\text {орг }}$ характерных для растительных (водорослевых) и белковых остатков, а также, установлено, что РОВ изменено в условиях нагревания не выше $300{ }^{\circ} \mathrm{C}$. В результате геохимического анализа ОВ было установлено, что РОВ находится на высокой стадии преобразования (ООВ > 99 \%). Но тип распределения полиароматических углеводородов (ПАУ) позволяет предположить, что исходное ОВ претерпело специфическую трансформацию под воздействием повышенных температур.

Bbводы. РОВ углеродисто-кремнистых пород Сафьяновского месторождения генетически однотипное, преимущественно сапропелевое, и его накопление связано сморскими условиями. Характерной особенностью является, с одной стороны, его полимеризованность, что типично для РОВ стадии позднего мезокатагенеза, а с другой стороны, его молекулярный состав не позволяет говорить о созревании РОВ в ходе диагенеза, что связано с ускоренным созреванием РОВ в результате контактного метаморфизма, либо гидротермального воздействия.

Ключевые слова: Сафьяновское медноколчеданное месторождение, углеродисто-кремнистые породы, рассеянное органическое вещество (РОВ), углеводороды, ЭПР-спектры.

Работа выполнена в рамках государственного задания Института геологии и геохимии им. академика А.Н. Заварицкого Уральского отделения РАН (Государственный регистрационный номер АААА - A18-118052590028-9).

\footnotetext{
$\bowtie$ soroka@igg.uran.ru

https://orcid.org/0000-0003-1360-6274

https://orcid.org/0000-0003-0231-302X

"Ivleonova@yandex.ru
} 
Авторы выражают благодарность главному геологу Н. В. Лещеву и коллективу ОАО «Сабьянмедь» за предоставление материалов для статьи. Наше исследование было подготовлено при частичной поддержке на средства субсидий, выделяемых в рамках государственной поддержки Казанского (Приволжского) федерального университета с иелью повымения его конкурентоспособности среди ведущих мировых научных и образовательных центров, а также за счет гранта Казанского федерального университета на выполнение общественные задания в сфере научной деятельности.

\section{СПИСОК ЛИТЕРАТУРЫ}

1. Язева Р. Г., Молошаг В. П., Бочкарев В. В. 1992, Геология Сафьяновского колчеданного месторождения (Средний Урал). Препринт. Екатеринбург. 71 с.

2. Ярославцева Н. С., Масленников В. В., Сафинна Н. П., Лещов Н. В., Сорока Е. И. 2012, Углеродсодержащие алевропелиты Сафьяновского $\mathrm{Cu}-\mathrm{Zn}$ колчеданного месторождения (Средний Урал). Литосфрера, № 2. C. 106-123.

3. Анфимов А. Л., Сорока Е. И., Ярославцева Н. С., Главатских С. П. 2011, Генезис углеродисто-кремнистских прослоев в рудовмещающей вулканогенно-осадочной толще Сафьяновского Сu колчеданного месторождения (Средний Урал), Вулканизм и геодинамика. V Всероссийский Симпозиум по вулканологии и палеовулканологии Екатеринбург. С. 474-476.

4. Чувашов Б. И., Анфимов А. Л., Сорока Е. И., Ярославцева Н. С. 2011, Новые данные о возрасте рудовмещающей толщи Сафьяновского месторождения (Средний Урал) на основе фрораминифер, ДАН. Т. 439, № 5. С. 648-650.

5. Чувашов Б. И., Анфимов А. Л., Сорока Е. И., Ярославцева Н. С. 2012, Девонские фрораминиферы с некарбонатной раковиной в рудовмещающей толще Сафьяновского месторождения // Литосфрера. № 5. С. 114-126.

6. Сорока Е. И., Молошаг В. П., Леонова Л. В., Петрищева В. Г., Ярославцева Н. С. Кремнисто-углеродистые отложения рудовмещающей толщи Сафияновского Си-Колчеданного Месторождения (Средний Урал) // Ежегодник-2009. ИГГ УРО РАН. 2010. С. $250-254$.

7. Муравьев. Ф. А., Винокуров В. М., Галеев А. А., Булка Г. Р., Низамутдинов В. М., Хасанова Н. М, Парамагнетизм и природа рассеянного органического вещества в пермских отложениях Татарстана // Георесурсы. 2006. № 2 (19). С. $40-45$.

8. Хасанов Р. Р., Галеев А. А. Минералообразующая роль захороненных растительных остатков в процессе гидрогенного медного рудогенеза // Изв. вузов. Геология и разведка. 2004. № 1. С. 18-22.

9. Галеев А. А., Филиппов М. М. Природа дефектов молекулярной структуры высших антраксолитов по данным ЭПР-спектроскопии // Геология и полезные ископаемые Карелии. 2005. Вып. 8. С. 121-127.

10. Неручев С. Г. Справочник по геохимии нефти и газа. СПб .: ОАО «Недра», 1998. 576 с.

11. Корчагина Ю. И., Четверикова О. П. Методы исследования рассеянного органического вещества осадочных пород. М.: Недра,1976. $230 \mathrm{c}$.

12. Петрова В. И., Батова Г. И., Куршева А. Б. и др. Органическое вещество донных осадков Обской губы: распределение, природа, источники // Геохимия. 2010. № 2. С. 1-13.

13. Романкевич Е. А. Геохимия органического вещества в океане. М.: Наука, 1977. 256 с.

14. Костырева Е. А. Геохимия и генезис палеозойских нефтей юго-востока Западной Сибири. Новосибирск: Изд-во СО РАН, «Гео», 2005. $183 \mathrm{c}$.

15. Шанина С. Н., Голубев Е. А., Бурдельная Н. С. Углеводороды-биомаркеры в шунгитах Карелии // Геохимия. 2013. № 9. С. 842-848.

16. Филиппов М. М. Шунгитоносные породы Онежской структуры. Петрозаводск: Карельский НЦ РАН, 2002. 280 с.

17, Моргунова И.П., Иванов В.Н., Литвиненко И.В., Петрова В.И., Степанова Т.В., Черкашов Г.А. Геохимия органического вещества донных отложений гидротермального поля Ашадзе (13ํ‥ш., Срединно-Атлантический хребет) // Океанология. 2012. Т. 52, № 3. С. 372-380. 18. Шульга Н. А., Пересыпкин В. И., Ревельский И. А. Изучение и состав н-алканов в образцах гидротермальных отложений Срединно-Атлантического хребета с помощью метода газовой хроматографии / масс-спектрометрии. // Океанология. 2010. Т. 50, № 4. С. 515-523.

19. Шульга Н. А., Пересыпкин В. И. О генезисе углеводоводов поля Лост Сити и Рейнбоу (Срединно-Атлантический хребет) // ДАН.2012. T. 445, № 2. C. 196-199.

20. Сафина Н. П., Анкушева Н. Н., Мурзин В. В. Физико-химические условия фрормирования барита из рудных фрорм Сафьяновского Си - Zn-колчеданного месторождения (Средний Урал) // Литосфера. 2012. № 3. С. 110-126.

21. Сорока Е. И., Молошаг В. П., Филиппов В. Н., Галахова О. Л., Причин М. Е. Хлорит из околорудных вулканогенных пород Сафьяновского развития // XIII Всероссийские чтения памяти В. О. Полякова. Миасс, 2012. С. 67-73. 